\title{
Does Corporate Liquidity Affect the M\&A Decisions and Methods of Payment? Evidence in ASEAN Listed Firms
}

\author{
Vania Tanudjaja \\ Departement of Management, Faculty of Economics and Business \\ Universitas Indonesia \\ Depok, Indonesia \\ vaniatan90@gmail.com
}

\author{
Eka Pria Anas \\ Departement of Management, Faculty of Economics and Business \\ Uniiversitas Indonesia \\ Depok, Indonesia \\ ekapanas@yahoo.com
}

\begin{abstract}
Using a probit model and data of 743 merger and acquisition deals of ASEAN listed firms over the period 2007 to 2017; this research studies the extent that liquidity impacts firms' cash capacity in corporate investing decisions. We examine whether high liquidity firms decide to join a merger and acquisition's bidding process and whether it affects their choice of payment method. We observe that high liquidity firms have managed their excess cash well through investments, and the probability of being M\&A bidders is high. We found that high growth firms are likely to use cash payments in acquisitions. This more strongly affects financially constrained bidders, who face greater opportunity costs in holding cash.
\end{abstract}

Keywords- M\&As, method of payment, liquidity, financing, capital structure

\section{INTRODUCTION}

Mergers and acquisitions (M\&As) are an option for corporate investment activity for listed and non-listed corporations [1]. M\&As are used by firms to gain competitive advantage in the business, to strengthens position with peers and unrelated industries, to obtain efficiency in the allocation of their capital structure, and increase growth potential. For non-listed companies, companies can do M\&A as an alternative means of listing to enter the capital market in a particular country, because there is a cheaper cost alternative if the target company (the acquired company) is listed in the stock compared to doing the costs of issuing equity [2]. Because of those benefits for investment purposes, as well as business expansion, M\&A has become the preferable investing activity, demonstrated by the increase in M\&A activities in the world over the last 15 year, as shown in table I.

Based on Thomson Reuters M\&A Datastream [3], the value of transactions worldwide saw an increase of USD 1,243 billion in 2002 to USD 3,601 billion in 2017. In terms of number of deals, there has been a growth in deals as a proxy for increased bidder activity (companies that intend to conduct M\&A and negotiate with a target company) of $80.11 \%$, where the number of deals increased from 27,455 in 2002 to 49,448 in 2017. The growing prospects of companies in the Asia-Pacific region and better growth in corporate performance compared to other state enterprises has made the Asia-Pacific region the second largest target region (in terms of value and amount deals) after the European region, The ASEAN region has attracted national and international cross-border M\&A activities The second interesting fact is that ASEAN has become the second most targeted region country for bidders (national and international) after China Hong Kong. The authors found that there were 22,955 M\&A deals in ASEAN countries during the study period (2007 to 2017), of which 3,349 acquirer transactions use consultant services while 19,607 transactions did not use consultant services.

So far, the M\&A payment method might be a valid approximation for the involved source of financing [4]. Liquidity, represented as the account Cash in a financial statement, is an important source of financing for firms in imperfect capital markets. Large cash accounts highlight the company capability to generate large amounts of internal

TABLE I. M\&A ANNOUNCEMENTS WORLDWIDE (2016-2017)

\begin{tabular}{|c|c|c|c|c|c|}
\hline \multirow[b]{2}{*}{ TARGET NATIONS } & \multicolumn{2}{|r|}{2016} & \multicolumn{2}{|l|}{2017} & \multirow[b]{2}{*}{ \%CHANGES IN Values } \\
\hline & $\begin{array}{c}\text { DEALS } \\
\text { NUMBERS }\end{array}$ & VALUE (Million USD) & DEALS NUMBERS & $\begin{array}{c}\text { VALUE } \\
\text { (Million USD) }\end{array}$ & \\
\hline EUROPE & 16.529 & $742.100,6$ & 14.804 & $867.516,8$ & $16,9 \%$ \\
\hline ASIA-PACIFIC (ex-Japan) & 13.544 & $836.950,6$ & 13.825 & $956.820,3$ & $14,3 \%$ \\
\hline North Asia (China, HongKong) & 8.600 & $617.391,3$ & 8.529 & $704.905,3$ & \\
\hline South East Asia (ASEAN) & 2.117 & $71.683,0$ & 1.985 & $95.592,3$ & \\
\hline Australia and New Zealand & 1.498 & $90.434,9$ & 1.812 & $93.585,7$ & \\
\hline South Asia & 1.257 & $56.834,3$ & 1.436 & $60.016,9$ & \\
\hline Central Asia & 72 & 607,1 & 63 & $2.720,1$ & \\
\hline AMERICAS & 48.250 & $1.866 .827,8$ & 16.994 & $1642.452,5$ & $-12,0 \%$ \\
\hline Japan & 2.496 & $82.720,6$ & 2.661 & $71.862,9$ & $-13,1 \%$ \\
\hline AFRICA \&MIDDLE EAST & 1.278 & $82.315,0$ & 1.227 & $65.489,0$ & $-20,4 \%$ \\
\hline \multicolumn{6}{|c|}{ SOURCES: THOMSONREUTERS M\&A DATABASE } \\
\hline
\end{tabular}


funds and high capacity growth firms [5]. The underlying rationale is that companies only have access to a very limited amount of cash at a given point in time. An interesting question is whether high and growing levels of corporate liquidity are linked to the surge in M\&A decisions. The higher the availability of internal funding, the higher the company's financial liquidity level; thus liquidity is one of the factors driving the acquisitions process [6].

This paper seeks to investigate the investment decisions based on capital capacity in M\&A Deals in ASEAN. The past literature has presented contrarian facts in research results. Yang et al. [5] found that bidders (acquirers) with the availability of liquid cash holdings tend not to use the $100 \%$ cash payment method, and prefer to use mixed payments. Yang et al. also found that by making cash acquisitions, there was a decrease in "post-performance" in the bidder companies. Li et al. (2017) found that of 57 countries that were subjected to cross-border mergers of target companies, there was a relationship between payment methods and the availability of cash holding, where overleveraged firms, stock payments, and underleverage firms used more mixed payment proportion; that is, they used cash and debt to fund M\&A projects (Burch et al.) [2]. Huang et al. [7] stated that for cross-border mergers, acquirer companies are more likely to use stock payments than mixed payments, multiplying the bidder's bid process, but raising risk in the M\&A process, increasing the default bidder's success. The results of this research found that the cash payment method shortens the bidder's deal process, helping the bidder to succeed, but there is risk of leverage in the company's capital structure, so this is only done in domestic M\&A.

\section{LITERATURE REVIEW AND HYPOTHESIS DEVELOPMENT}

The empirical investigation lights onto two aspects of the source of financing, the decision to join an M\&A bid and the source of the M\&A payment method. Capital structure theories state the existence of capital market imperfections contributes to financial frictions, therefore firms prefer to use internal financing rather than costly external financing (bank loans, debt, or equity (Myers, 1984)). Firm Liquidity (proxy by internal financing) allows financially constrained firms to invest without having to access new costly external financing. Therefore, firm's liquidity is the crucial point in investment decisions, include M\&A. Higher liquidity means high financial capability in enhancing firm's M\&A activities [1].

We examined this study based on these two contrarian theories. First, the pecking-order theory implies that firms prefer using internal than external financing. When internal funds are insufficient, external funds are required. Firms tend to choose the safest external financing, such as debt, in order to lower the firm's leverage. This is the based fact that cash payments are often financed with internal funds or bank loans [6]. Many previous studies, such as Yang [7] and Erel et al. [8], had in-line results with the pecking-order theory, which cash-rich firms used internal financing (proxy by cash holding) as first option to funding their M\&A payment. They used internal financing for small-cap M\&A and the combinations of external financing are needed for big-cap M\&A. Sufficient cash holdings derive a corporate decision to invest, include M\&A [1]. A firm makes investment decisions where the firm has a large about of cash holding to avoid perceptions of inefficient management of internal funds.

\section{H1: Sufficient cash holdings may affect the corporate decision to join the bidding on an M\&A.}

Second, the trade-off theory implies that a company prefers to use external financing (equity and issuing debt) to get a tax-shield benefit. Firm get the trade off benefits to pay lower tax if they use external financing, rather than using whole internal financing in their investment activities. Trade off theory assumes that there is an optimal amount of debt for any firms, thus this debt amount become the rational target debts level. These rational target debts level will be considered for the investment payment method, by uses them in financing proportion between external financing options. This theory is in line with free-cash-flow theory (Jensen, 1986), which state that loans from banks might be beneficial rather than binding firm's free cash flows from shareholders. Banks are going to screen and implement monitoring process on investment projects when loans is granted. Therefore, banks willingness to lend money for firm investment project implies a positive investment signal to outside investors. If internal funding is insufficient for M\&A, credit financing is preferred based on possible bank screening.

Fischer [4] examined a sample of 610 acquisitions over period 1991 to 2009. They distinguished several different sources of financing for sizable transactions. If a takeover is financed with internal funds, the acquirer's pre-takeover characteristics (cash level, TobinQ, and leverage) are crucial. In contrast, $\mathrm{Hu}$ and Yang [9] examined a sample of 85,560 cross-border M\&A in 57 countries between 1990 to 2010. They found that higher leverage firms are less likely to acquire foreign targets, whereas lower leverage firms tend to be targets and been acquired by foreign firms. Firms adjust their capital structure after an acquisition by issuing more equity if they were overleveraged, or issuing more debt if they were underleveraged before the acquisition.

H2: Sufficient cash holdings may affect a corporate decision to in selecting the method of payment in M\&A

\section{RESEARCH METHOD}

The research sample is the data of all bidder companies that meet the following requirements: (1) the company is consistently listed; (2) the company publishes annual financial statements available at Thomson Reuters data sources in units of millions of USD (the rate is automatically adjusted from Thomson Reuters Eikon Datastream Source); (3)the value of a deal transaction is not worth zero USD; and (4) the company has stock price data (historical prices) available daily on Bloomberg Datastream sources. There are three stages of elimination of population data for the sample research conducted by the author. In Stage 1, the sample data is filtered from the 3,349 pieces of M\&A population data using Financial Advisors (FA). We compared the M\&A data list on the FA account to the Thomson Reuters Datastream source to condense the list to $2,747 \mathrm{M} \& \mathrm{~A}$ data points. In Stage 2, we eliminated M\&A data with transaction values below USD 1 million, resulting in 2,107 M\&A data. In Stage 3 , we crosscheck the M\&A data with the bidder company's financial statements on Thomson Reuters data sources and historical stock data recorded on Bloomberg to choose the public companies that have the necessary data, such as cash and cash equivalents, total assets, total liabilities, current assets, current liabilities, PE Ratio, CAPEX, depreciation, M\&A deals data (methods of payment, business industry of bidder and target, and reasons for M\&As). Because bidder 
firms are eliminated as non-public (private) companies, there is no data available in Thomson Reuters and Bloomberg, leaving a selection of $736 \mathrm{M} \& \mathrm{~A}$ transactions. Of the final sample of $736 \mathrm{M} \& \mathrm{~A}$ deals, 573 were in the non-financial sector. Looking at the M\&A payment method, we found that out of the 736 deals, 479 deals used a cash payment method ( $100 \%$ cash or a mixture of cash with debt or equity), and the remaining 257 deals used non-cash funding.

This study uses unstructured panel data, in which the research panel data is a composite of the sample company's sample data within the time period of the study (2007 2017); subsequently, the bidder company's one-deal data is only used during the year of the M\&A deal. This causes the panel data to be unbalanced. The research variables are ratio data, nominal variables and dummy variables. Considering the dummy data, the authors used the probit regression method and tested statistical assumptions (multicolinearity and heteroskedacity). The data were given a heteroskedacity (White test) treatment before the probit regression; there is no problem of heteroskedacity. To determine whether there is a multicolinearity problem between the independent and control variables, the authors ran a correlation test in Eviews against the independent variables and controls used in two probit regression models (Model $1, \mathrm{y}=\operatorname{bidder}(\mathrm{y}=0$ or $\mathrm{y}=$ $1)$; and Model 2, $\mathrm{y}=$ payment $(\mathrm{y}=0$ or $\mathrm{y}=1)$ ). This study focuses on two research models. Model 1 tries to examine cash holding factors (XCash) and other factors that influence corporate decisions to bid in M\&A actions. This model, according to Yang [5] can be described with the following equation:

$$
\begin{aligned}
& \text { Bidder }_{i . t}=a+b_{1} \text { Xcash }_{i, t}+b_{2} \text { StockPrice }_{i, t} \\
& +b_{3} \text { Tobin }_{i, t}+ \\
& b_{4} R O A_{i, t}+b_{5} \text { SalesGrowth }_{i, t}+b_{6} N W C_{i, t}+ \\
& b_{7} \text { Leverage }_{i, t}+b_{8} P E_{i, t}+b_{9} \text { Size }_{i, t}+ \\
& b_{10} R O A * \text { Tobin }_{i, t}
\end{aligned}
$$

where the dependent factor is the variable Bidder (the dummy variable), the independent variables are Excess Cash (XCash), and the factors that influence corporate decisions to join as bidders (StockPrice, TobinQ, ROA, SalesGrowth, NWC, Leverage, PE, Size and ROA * TobinQ). The XCash variable interprets the difference in the value of cash on the observation of the research firm with the value of the cash in the company (fitted). The result of XCash is obtained from a regression equation and the result of the fixed-effect estimation equation of Oppler [10] as formulated in the following equation:

$$
\begin{aligned}
& \text { Cash }_{i . t}=a+b_{1} \text { TobinQ }+b_{2} \operatorname{SIZE}_{i, t}+b_{3} C F_{i, t}+ \\
& b_{4} N W C_{i, t}+b_{5} \text { CAPEX }_{i, t}+b_{6} L E V E R A G E_{i, t}+b_{7} \operatorname{DIV}_{i, t}
\end{aligned}
$$

$$
{\text { X } \operatorname{cash}_{i, t}=\text { Cash }_{i . t^{-}} \text {Fitted Cash }}_{i . t}
$$

Model 2 tries to examine the cash holding factor affecting the bidder company's decision to use cash in M\&A compared to other funding methods, such as using stock or debt payments(). This model, according to Yang [5], can be described as the following equation:

$$
\begin{aligned}
\text { Payment }_{i . t}= & a+b_{1}{\text { X } \text { cash }_{i, t}+b_{2} \text { Leverage }_{i, t}+} \\
& b_{3} \text { CB }_{i, t}+b_{4} \text { CF }_{i, t}+b_{5} \text { PUBLICDEALS }_{i, t}+ \\
& b_{6} \text { DEALVALUE }_{i, t}+b_{7} \operatorname{dIVERSIFY}_{i, t}+ \\
& b_{8} \text { COMPLETE }_{i, t}
\end{aligned}
$$

where the dependent factor is the variable Payment (a dummy variable), the Independent variables are Excess Cash $\left(\operatorname{Xash}_{i, t}\right)$, and factors influencing corporate decision to join as bidder ( Leverage, CB, CF, PUBLICDEALS, DEALVALUE, DIVERSIFY, COMPLETE). This study uses an associative hypothesis, which is a statement that indicates the allegations about the relationship between two or more variables. In this study the influence of independent variables (cash holding factor) on the dependent variables (corporate decisions to bid on M\&A and cash payment method of an M\&A).

\section{EMPIRICAL ANALYSIS}

\section{A. Model 1}

Model 1 examines whether there is a cash holding factor opportunity (proclaimed by XCash) influences corporate decisions to join as bidders in merger and acquisition actions M\&A. Based on the research of each model, we tried to compare the results of our entire sample inputs (736 M\&A data) and M\&A data samples that included only nonfinancial sector firms (573 M\&A data. The results of the regression summary below show that there is a consistency of model 1 significance tested in two different sample data types, which are data samples of 736 data and sample M\&A data on the 573 non-financial corporations. Assessed by the $\mathrm{Z}$-stat test, there is consistency in the XCash variable's significance, which has an opportunity to influence the dependent variable (bidder) with a $99 \%$ confidence level. There is also an opportunity for control variables (ROA) to influence the dependent variable (bidder) with a $90 \%$ confidence level. This explains that other control variables (Stock-price, TobinQ, Annual Sales Growth, NWC, Leverage, PE and TobinQ * ROA) have no chance of influencing corporate decisions to bid on M\&A actions.

The results in figure 1 above show that with the probability value (LR Stat) of 0.011853 in the 736 data samples and 0.01532 in the 573 data samples (both with a $95 \%$ significance level), Hypothesis 1 is accepted, that is, the independent variables and control variables potentially affect the dependent variable. The result of the pseudo R2 is 0.029581 with a 95\% significance value (Prob.LR Stat) in 736 data sample. That is, this model can only describe the opportunity of cash holding factor affecting corporate decision to join as a bidder in merger and acquisition action M\&A of $2.9581 \%$ with a $95 \%$ significance in all M\&A data. The result of pseudo R2 is 0,03631 with a 95\% significance value (Prob.LR Stat) in the 537 data sample. That is, this model can only illustrate the cash holding factor opportunity to influence corporate decisions to join as a bidder in merger and acquisition action M\&A of $3.631 \%$ with $95 \%$ significance in all M\&A data.

In 736 data samples, model results show for $(y=0)$, there is a $21.36 \%$ chance of true model and dependent variable (Bidder) can be explained by independent variables (XCash) and supported by control variables. The model results show for $(y=1)$, there is a probability of an $81.52 \%$ true model and the dependent variable (Bidder) can be explained by independent variables (XCash) and supported by the control variables. In the 537 data samples, the model results show for $(y=0)$, there is a $22.37 \%$ chance that the true model and the dependent variable (Bidder) can be explained by the independent variable (XCash) and supported by the control 
variables. The model results show for $(y=1)$, there is an opportunity that $77.63 \%$ of the true model and dependent variable (Bidder) can be explained by independent variables (XCash) and supported by the control variables.

TABLE II. MODEL 1 RESUlT

\begin{tabular}{|c|c|c|c|c|}
\hline \multicolumn{3}{|c|}{ 736 DATA } & \multicolumn{2}{|c|}{ 573 DATA } \\
\hline $\begin{array}{l}\text { Variabel Independen } \\
\text { dan Control }\end{array}$ & Penduga & Significant & Penduga & Significant \\
\hline Konstanta (c) & 0,89098 & & 0,92411 & \\
\hline $\mathrm{X} 1$ (Xcash) & 0,0000143 & $* * *$ & $1,7 \mathrm{E}-05$ & $* * *$ \\
\hline Stock Prize & 0,061073 & & 0,12914 & \\
\hline TobinQ & 0,0000131 & & $2,2 E-05$ & \\
\hline ROA & 0,132464 & * & 0,17259 & * \\
\hline SalesGrowth & 0,001359 & & 0,00053 & \\
\hline NWC & $-0,011798$ & & $-0,037$ & \\
\hline LEVERAGE & $-0,23857$ & & $-0,32$ & \\
\hline PE & $1,35 \mathrm{E}-07$ & & $3,6 \mathrm{E}-07$ & \\
\hline TOBINQ*ROA & $-1,67 \mathrm{E}-05$ & & $-1 \mathrm{E}-05$ & \\
\hline Mcfadden R2 & 0,029581 & & 0,03631 & \\
\hline Prob (LR Stat) & 0,011853 & $* *$ & 0,01532 & $* *$ \\
\hline$\%$ Correct Model & & \%Prob. & & \%Prob. \\
\hline$y=0$ & 21,36 & 19,02 & 22,37 & 19,37 \\
\hline$y=1$ & 81,52 & 80,98 & 81,32 & 80,63 \\
\hline \multicolumn{5}{|l|}{$\%$ Incorrect Model } \\
\hline$y=0$ & 78,64 & 80,98 & 77,63 & 80,63 \\
\hline$y=1$ & 18,48 & 19,02 & 16,68 & 19,37 \\
\hline
\end{tabular}

Assessed by the z-stat test, there is also an opportunity for the influence of control variables (ROA) on the dependent variable (bidder) with a 90\% confidence level. This explains that other control variables (Stock-price, TobinQ, Annual Sales Growth, NWC, Leverage, PE and TobinQ * ROA) have a low chance of influencing corporate decisions to join as bidders in merger and acquisition action M\&A. The XCash result has significant influence to explain the dependent (bidder), i.e. corporate decision becomes bidder in M\&A corporate action in ASEAN during the study period, although the value of its influence is still small, that is 0,0000143 in sample 736 companies, and 0,000017 on sample 573 non-financial companies. It is only brought $1 \%$ explain whether there is influence of the amount of excess cash in company owned company to the company decision to do action of M\&A. These results support previous studies (Yang et al., [5] and Li et al., 2017) where there exists the influence of XCash (excess-cash) on corporate decisions into bidders in M\&A. M\&A action is one investment action companies that require substantial funding. Burch et al. [2] suggest that financially restricted firms judge their cash holdings more because liquidity allows them to invest without having to access new debt or equity; thus, corporate liquidity should play an important role in investment decisions including acquisitions. Specifically, liquidity may allow a company to make acquisitions, because liquidity can be used directly as a guarantee of payment or can be used to meet interest payments on debt financing. Therefore, an increase in corporate liquidity should increase a company's acquisition activities. Hence, the existence of a firm with excess cash reflects the increasing liquidity of bidder companies, so there is an opportunity for bidder companies to join in the investment process, either by M\&As, or investing in existing companies (both cross border and domestic).

With the increase of corporate liquidity, the availability of large amounts of free cash funding may cause an opportunity for misuse of funding within the company, where the internal managerial interests of the company are for personal gain rather than for shareholder use. This is similar to Yang's [5] study on the object of M\&A research in China, where the results show the a high probability for agency problems in Chinese firms in which Chinese firms invest in a corporation that is in the growth or maturity stage to minimize free money (free-cash-flow) in the company and minimize the misuse of cash money.

The result of this research also shows that there is a chance of correlation in controlling the ROA variable to influence the dependent variable, i.e. the company's decision to become a bidder in an M\&A in the ASEAN in the period 2007 to 2017. The higher the value of ROA, the more efficient the company uses its assets to earn revenue. If seen, Net Income is one of the contributors in cash companies [6]. If a company can derive or contribute to the cash increase factor from net income, then there is a cash opportunity generated by the company, allowing it to invest. Cash holding is the availability of the company's cash funds after allocating to meet the daily operational needs of the company. Cash can be used by a company to invest, in capital equipment to support the company's operational activities or in other firms through M\&As. Cash becomes a company's main funding because with efficient and effective management, a company can avoid operational loss and can precisely set appropriate funding structures for the company's activities and investment activities. For investors, financial analysts, and all parties who view a firm's financial statements, cash is one of the main points viewed. A lack in cash holding causes a negative perception of the company's financial performance. It can signal poor management of funds to support the activities of the company and can even signal bankruptcy. Comparatively, the existence of excess cash holding may cause negative perceptions as well, because it may signify conflict of interest among the managerial party to meet personal needs or managerial inefficiency in managing cash when it is allowed to remain idle.

There is a chance that independent factors other than $\mathrm{XCash}$ are capable of explaining the dependent factor (bidder) taking M\&A action in the ASEAN during the study period; there is a conjecture that corporate strategy, managerial review and other corporate actions impact and influence corporate decisions to bid [1]. Factors beyond this XCash have not been studied further.

\section{B. Model 2}

Model 2 examines whether there is a chance that the cash holding factor affects a firm's decision to use "cash" in M\&A over other funding M\&A methods, like stock or debt payments. Based on the research of each model, we compared the results of the entire 736 sample inputs and the data samples of only the 573 non-financial sector firms. Assessed by the z-stat test, there is consistency in the significance of XCash variables that influence the dependent 
variable (bidder) with a 95\% confidence level on the 736 data samples, and an increase to $99 \%$ in the 573 data samples. It is seen that the test results of Model 2 in both types of samples show the variables $\mathrm{CB}, \mathrm{CF}$, public-offer section (dummy variable), and offer section-value are likely to affect the company's decision to use cash in a M\&A compared to other funding methods (like stock or debt payments or other funding sources). The variable of "leverage, diversifying and complete" are not included in the significance because the z-stats probability values are above the $90 \%$ significance error limit.

The above results show that a probability value (LR stat) of 0.0001475 in the 736 samples and 0.000326 in the 573 samples (both with a significance level of 99\%), meaning that Hypothesis 1 is accepted, meaning the independent variable and control variables together potentially affect the dependent variable. The result of the pseudo R2 is 0.026394 with a 99\% significance value (Prob.LR Stat) in the 736 sample. That is, this model only describes that the factor of cash holding influences the decision of the bidder company to use cash in an M\&A $2.6934 \%$ of the time with $95 \%$ certainty. The result of the pseudo R2 is 0.039158 with $99 \%$ significance value (Prob.LR Stat) in the 537 sample. That is, this model only describes that the factor of cash holding influences the decision of the bidder company to use cash in an M\&A $3.9158 \%$ of the time with $99 \%$ significance across.

TABLE III. MODEL 2 RESULT

\begin{tabular}{|c|c|c|c|c|}
\hline \multicolumn{3}{|c|}{736 DATA } & \multicolumn{2}{|c|}{573 DATA } \\
\hline $\begin{array}{l}\text { Variabel } \\
\text { Independen dan } \\
\text { Control }\end{array}$ & Penduga & Significant & Penduga & Significant \\
\hline Konstanta (c) & 0,433399 & 0,0102 & 0,314575 & 0,0848 \\
\hline X1 (Xcash) & $-7,22 \mathrm{E}-06$ & ** & $-0,000011$ & $* * *$ \\
\hline LEVERAGE & 0,249548 & & 0,318663 & \\
\hline CF & $-0,181848$ & & $-0,187832$ & $* *$ \\
\hline $\mathrm{CB}$ & 0,181347 & $*$ & 0,361678 & $* * *$ \\
\hline PUBLIC DEALS & $-0,175117$ & $*$ & $-0,188405$ & $*$ \\
\hline DEALS VALUE & $-2,8 \mathrm{E}-08$ & $* * *$ & $-2,8 \mathrm{E}-08$ & $* *$ \\
\hline DIVERSIFYING & 0,070185 & & 0,14833 & \\
\hline COMPLETE & $-0,185035$ & & $-0,196055$ & \\
\hline Mcfadden R2 & 0,026394 & & 0,039158 & \\
\hline Prob (LR Stat) & 0,001475 & $* * *$ & 0,000326 & $* * *$ \\
\hline$\%$ Correct Model & & \%Prob. & & $\%$ Prob. \\
\hline$y=0$ & 37,03 & 34,92 & & \\
\hline$y=1$ & 66,22 & 65,08 & & \\
\hline \multicolumn{5}{|l|}{$\%$ Incorrect Model } \\
\hline$y=0$ & 62,97 & 65,08 & & \\
\hline$y=1$ & 33,78 & 34,92 & & \\
\hline
\end{tabular}

In the 736 samples, the model results show that for $(y=$ 0 ), there is a $37.03 \%$ chance of a true model and that the dependent variable (Payment) can be explained by independent variables (XCash) and supported by the control variables. The model results show for $(y=1)$, that there is a $66.22 \%$ chance of a true model and that the dependent variable (Payment) can be explained by the independent variable (XCash) and supported by the control variables. In the 537 samples, the model results show that for $(y=0)$, there is a $37.65 \%$ chance of a true model and that the dependent variable (Payment) can be explained by the independent variables (XCash) and supported by the control variables. The model results also show that for $(y=1)$, there is a $67.11 \%$ opportunity of a true model and that the dependent variable (Payment) can be explained by the independent variables (XCash) and supported by the control variables.

The results of this study suggest that XCash is still likely to affect the dependent variable (payment method) of M\&As. This is not in line with the research of Li et al. (2017) who found that of the 57 countries that were the object of crossborder mergers of a target company, the relationship between the method of payment and the availability of cash holding companies, underleveraged companies use more proportion of mixed payment, i.e. cash and debt to finance M\&A projects. Huang et al. [7] stated that for cross-border mergers, the acquiring companies are more likely to use stock payments rather than mixed payments, multiply the bidder's bid process, but risk increasing the M\&A deals process, increasing the success of the default bidder process. The results of their research found that the cash payment method will shorten the bidders' deal process, so the bidder process can succeed, but there is risk of leverage in company's capital structure, so it is only done in domestic M\&As. The results of this study are in line with Erel et al. [8] who show a significant positive relationship of the availability of internal funding to increase M\&A deals in the UK. The results of this study are also in line with the results of Burch et al. [2] which found that for big deals (above 50 billion USD) there is a significance between internal funding and the creation of corporate value, resulting in more use of internal funding for M\&As. There is a chance that independent factors other than XCash are capable of explaining the dependent factor, i.e. the corporate decision to bid on an M\&A in the ASEAN countries during the study period. There is a conjecture that factors like corporate strategy, managerial review, or other corporate actions may impact the company's decisions [1]. Factors beyond XCash have not been thoroughly studied further.

If observed further, then the selection of M\&A payment method is also based on the need for substantial M\&A funds, so companies must be able to choose the right funding, whether cash funding only or non-cash funding (like debt or equity). The majority of research results study cash versus non-cash. (Data can be seen in table 4) Amihud et al. [11] in their research on corporate control and selection of funding types in the M\&A process, state that mergers and acquisitions should not only be considered as business transactions, but should be seen as a comprehensive process that includes the pre-combination stage, integration stage, and assessment. Therefore, companies must take appropriate steps at each stage; thus competitive advantage due to mergers and acquisitions can be achieved. In funding an M\&A action, substantial funding is required, so allocating funding sources is very important for the acquiring company. With regard to two types of funding sources, a company will determine the type of funding action in the M\&A based on the main funding factors, namely the availability of internal cash (cash holding) after 


\begin{tabular}{|c|c|c|c|c|c|}
\hline \multicolumn{6}{|c|}{ TABLE IV RESEARCH MODEL AND VARIABLES EXPLANATIONS } \\
\hline \multicolumn{3}{|r|}{ MODEL 1} & \multicolumn{3}{|r|}{ MODEL 2} \\
\hline Type of Variables & Variables & EXPLANATIONS & Type of Variables & Variables & EXPLANATIONS \\
\hline Dependent & Bidder & $\begin{array}{l}\text { "1"if corporate is willing to join bidder; "0" if } \\
\text { corporate is not willing to join bidder }\end{array}$ & Dependent & Payment & $\begin{array}{l}\text { "1"if the corporate uses cash; " } 0 \text { " if the corporate does } \\
\text { not use cash }\end{array}$ \\
\hline \multirow[t]{13}{*}{ Independent } & Xcash & Excess Cash = optimal level cash, see the Equitation 3 & Independent & Xcash & Excess Cash = optimal level cash, see the Equitation 3 \\
\hline & Return & Annual Stock Returns & & Return & Annual Stock Returns \\
\hline & Tobin & MARKET TO BOOK RATIO & & Tobin & MARKET TO BOOK RATIO \\
\hline & ROA & NET INCOME / TOTALASSET & & ROA & NET INCOME / TOTAL ASSET \\
\hline & Tobin*ROA & Tobin*ROA & & Tobin*ROA & Tobin*ROA \\
\hline & PE & Price Earning Rasio & & PE & Price Earning Rasio \\
\hline & Size & logarithm of total asset & & Size & logarithm of total asset \\
\hline & leverage & (short term debt + long term debt / total asset) & & leverage & (short term debt + long term debt / total asset) \\
\hline & sales growth & annual rate of growth sales & & sales growth & annual rate of growth sales \\
\hline & nwc & (current asset-current liabilities-cash)/ total asset & & nwc & (current asset-current liabilities-cash)/ total asset \\
\hline & & & & friendly & dummy variable, if "1" is a friendly, "0" is unfriendly \\
\hline & & & & $C B$ & $\begin{array}{l}\text { cross border, a dummy variable, "1" if cross border, "0" } \\
\text { if not-cross border }\end{array}$ \\
\hline & & & & $\overline{C F}$ & CASH FLOW, (net profit+depreciation / total asset) \\
\hline
\end{tabular}

deducting the operational funding allocation of the company, so as not to disrupt the company's operational funding activities. Thus, funding methods can have a direct impact on or be influenced by the company's decision to choose the right method of payment, because it affects the availability of cash holding to be used by the company and the target leverage set by the company in its capital structure [4]. In the ASEAN countries performing M\&As in 2007 to 2017, most tended to use internal funding, which involves cash financing and an optimal combination of funding with a cash element, rather than choosing non-cash financing (like a debt and equity combination). The bidder countries in the M\&A ASEAN 2007-2017 are primarily Asian countries, with a greater proportion of Asia-Pacific (China, Hong Kong, South Korea) and ASEAN bidders than European or United States bidders. This supports the research statements of Yang (2017) and Li et al. (2017), showing a shifting between bidder countries from the European Union and the US to the Asia-Pacific region. This is also evidenced by the many levels of cash retained by Asian-Pacific companies, signifying the economic development of the region. Quoting the Thomson Reuters database (2017), an increase in investment, especially in the Asian region by Asian bidders, has signaled an increase in liquidity in the Asia-Pacific countries.

Properly managed cash holdings are an efficient and effective source of continuity for funding a company. Cash holdings has become an important study area in recent years amid firms' competitive responses to the challenges of the economic growth in many countries (Burch et al. [2]). As companies consider the marginal benefits and the cost of holding liquid assets, the trade-off theory perspective in cash holding management practices supports optimal cash rates, in which firms tend to hold cash for funding corporate activities and tend to have external financing to shield profits from taxes. In contrast, the pecking-order perspective states that firms with larger cash holdings are more likely to avoid risks, thus choosing internal funding first, followed by new external funding with the lowest risk level (debt to third parties). The level of corporate leverage is also affected by the use of cash holding, in which the large amounts of cash holding over time will decreases a company's liquidity level, resulting in rebalancing of its capital structure to meet its financing needs ( $\mathrm{Li}$ et al. (2017). If funding a company's operating activities are problematic due to a decrease in corporate liquidity (from substantial use of cash holdings) as a post-effect of investment financing, a firm will choose to pay for M\&A deals with cash or a non-cash method. In terms of type of M\&A, the results of this study indicate the existence of horizontal and vertical types of M\&A, where bidder companies are more likely to acquire non-similar companies compared with similar companies.

\section{CONCLUSION}

The results of this study indicate the possibility of a relationship between excess cash and a company's decision to become a M\&A bidder (demonstrated in Model 1) and between cash holdings and the method of payment for M\&As in the ASEAN in 2007 to 2017. The majority of bidder companies used cash financing rather than non-cash financing. This is due to the fact that most company's current asset composition is still converted to cash for the purpose of funding the company's investment. In Model 1, the independent factors XCash and ROA controls have the opportunity to influence corporate decisions to bid. In Model 2 , the independent factor XCash and other control factors (CB, CF, DEALS VALUE) have the opportunity to influence the company's decision of M\&A method of payment.

There are other independent factors other than XCash that are able to explain the dependent factor. There is a conjecture that factors like corporate strategy, managerial review and other corporate actions influence corporate decisions to bid [1]. Factors beyond XCash should be studied further. 


\section{REFERENCES}

[1] DePamphillis, D.M., (2015). Merger, Acquisitions and Other Restructuring Activities 8th ed.

[2] Burch, T. R., Nanda, V., \& Silveri, S. (2012). Taking stock or cash in? Shareholder style preferences, premiums and method of payments. Journal of Empirical Finance, 19(4), 558-582.

[3] Thomson Reuters Database, https://financial.thomson reuters.com

[4] Fischer, M. (2017). The source of financing in merger and acquisitions, The Quarterly Review of Economics and Finance, 65, 227-239.

[5] Yang, J., Guariglia, A., Guo, J. (2017) To what extent does corporate liquidity affect M\&A decisions, method of payment and performance? Evidence from China. Journal of Corporate Finance, 54, 128-152.
[6] Ross (2008). Corporate Finance 2nd Asian ed.

[7] Huang, P., Officer, M. S., \& Powell, R. (2016). Method of payment and risk mitigation in cross-border mergers and acquisitions. Journal of Corporate Finance, 40, 216-234.

[8] Erel, I., Jang, Y., Minton, B. A., \& Weisbach, M. S. (2017). Corporate liquidity, acquisitions and macroeconomic conditions. National Bureau of Economic Research Working Paper No. 23493.

[9] Hu, M. \& Yang, J. (2016), The role of leverage in crossborder mergers and acquisitions, International Review of Economic and Finance, 43, 170-199.

[10] Opler, T., Pinkowitz, L., Stulz, R., \& Williamson, R. (1999). The determinants and implications of corporate cash holdings. Journal of Financial Economic, 52(1), 346. 
